\title{
Heavy Metals in Heterobranchus Longifilis (Cuvier And Valenciennes, 1840) Cultured in Earthen Ponds in Selected Communities in Warri Metropolis, Nigeria
}

\author{
Wangboje O.M. ${ }^{1}$, Oguzie F.A. ${ }^{1}$, Ufua J. ${ }^{1}$ \\ ${ }^{1}$ Department of Aquaculture and Fisheries Management, Faculty of Agriculture, University of Benin \\ *Corresponding author. P. M. B. 1154, Benin City, Nigeria@ oiseoje.wangboje@uniben.edu
}

\begin{abstract}
The concentrations of Cadmium $(\mathrm{Cd})$, Copper $(\mathrm{Cu})$, Lead $(\mathrm{Pb})$ and Zinc $(\mathrm{Zn})$ in Heterobranchus longifilis (Mean total length= $40.52 \mathrm{~cm}$; mean weight=563.25 g) cultured in earthen ponds in Warri, Nigeria, were determined by Atomic Absorption Spectrometric technique in order to provide baseline data and to ascertain the suitability of such fish for consumption. The mean concentrations of metals in H. longifilis, ranged from $0.13 \mathrm{mg} / \mathrm{kg}$ for Cd in January to $72.51 \mathrm{mg} / \mathrm{kg}$ for $\mathrm{Cu}$ in June with significant differences $(\mathrm{p}<0.05)$ observed in the mean concentrations of $\mathrm{Cu}, \mathrm{Pb}$ and $\mathrm{Zn}$ in fish between months. The mean concentrations of metals in $H$. longifilis, ranged from $0.12 \mathrm{mg} / \mathrm{kg}$ for $\mathrm{Cd}$ at Jeddo to $69.27 \mathrm{mg} / \mathrm{kg}$ for $\mathrm{Cu}$ at Ubeji with significant differences $(\mathrm{p}<0.05)$ observed in the mean concentration of $\mathrm{Zn}$ in fish between stations. The bioaccumulation quotient (BQ) values ranged from 0.50 for $\mathrm{Cd}$ at Jeddo to 37.24 for $\mathrm{Cu}$ at Oboroke while the hazard quotient (HQ) ranged from 0.39 for $\mathrm{Zn}$ to 3.43 for $\mathrm{Pb}$. The maximum acceptable risk (MAR) values ranged from 0.02 for $\mathrm{Pb}$ at Ekpan to 6.29 for $\mathrm{Zn}$ at Ubeji while the estimated average daily intake (EADI) of heavy metals ranged from 0.09 $\mathrm{mg} /$ person/day for $\mathrm{Cd}$ to $36.13 \mathrm{mg} /$ person/day for $\mathrm{Cu}$. It was concluded that $\mathrm{Cd}, \mathrm{Cu}$ and $\mathrm{Pb}$ were the metals that presented a potential risk to the consuming public and that the heavy metal content in earthen ponds should be routinely monitored in order to keep metal levels within safe limits.
\end{abstract}

Keywords: Heavy metals, Hazard quotient, Heterobranchus longifilis.

\section{INTRODUCTION}

Heavy metals have gained attention from public and scientific communities globally owing to their toxicity to aquatic organisms and ultimate effects on humans (Jayaprabha et al., 2014). The presence of heavy metals in aquatic ecosystems in excess of natural background levels has also become worrisome around the world (Akoma and Uhunmwango, 2017). The factors which contribute chiefly to the deleterious effects of metals are their non-biodegradability and their ability to bioaccumulate and biomagnify in aquatic media (Olowu et al.,
2015). Ponds in close proximity to urban areas are inevitably subjected to urban runoff especially during the wet season (Reuben et al., 2018). ). Frimpong et al., (2014), observed that aquaculture in subsaharan Africa is conducted mainly in earthen ponds which are relatively less intensive compared to the same method of food production in Europe and America. The choice of earthen ponds to culture fish in Nigeria could be linked to its fast production owing to the vast availability of natural food which supplements feed given to fish (Omitoyin, 2007). Growth of natural food in ponds is largely stimulated by 
dissolved metals in form of minerals. Heavy metals associated with urban runoff are largely the same as those associated with municipal wastewater. According to the United Nations Educational Scientific and Cultural Organization/World Health Organization/United Nations Environment Programme (UNESCO/WHO/UNEP), water quality problems particularly associated with urban runoff are high levels of oil products and Lead $(\mathrm{Pb})$, both arising from the use of automobiles, as well as a variety of other metals and xenobiotics associated with local industrial activity (UNESCO/WHO/UNEP, 1996). In addition, heavy metals can blend with runoff from tires, car exhaust, road asphalt, fuel combustion, parking dust and recreational land (Reddy, 2014). It is on this premise that earthen ponds need to be investigated and scrutinized for heavy metal content as they are largely prone to runoff owing to their peculiar way of construction. There is paucity of data regarding the heavy metal concentrations in fish specifically raised in earthen ponds in Warri, along the Niger Delta belt of Nigeria, which has warranted this research, against the backdrop that the town is widely known for its crude oil exploration activities which may conceivably impact on such ponds owing to their exposed nature. Igbagara et al., (2016), Bluwey et al., (2018) and Olawuyi (2018) have recognized a litany of environmental impacts associated with crude oil extractive operations and activities in the Niger Delta, of which Warri is an integral part, which affect surface water. Such crude oil extraction operations can also impact on soil and air which in turn can influence community health (Johnston et al., 2019). A variety of heavy metals have been reported to be associated with crude oil extraction operations (Calamari and Naeve, 1994). Furthermore, earthen ponds are prone to both non-point and point sources of contamination especially the former. The fish species used in this study was Heterobranchus longifilis (Cuvier and Valenciennes, 1840). It was purposely selected for this research because it is the principal fish species cultured by farmers who operate earthen ponds in Warri. This is an important catfish species highly valued for food in Nigeria (Olaosebikan and Raji, 2013). Similarly, the heavy metals of interest namely: Lead $(\mathrm{Pb})$, Cadmium (Cd), Zinc $(\mathrm{Zn})$ and Copper $(\mathrm{Cu})$ are typically found in urban runoff along with Nickel and Chromium (Jang et al., 2005; Nabizadeh et al., 2005). Particularly Zinc and Copper are essential in trace quantities for the maintenance of cellular processes in man (Food Safety Authority of Ireland, 2009) while non-essential elements such as $\mathrm{Pb}$ and $\mathrm{Cd}$ do not play metabolic functions and can be toxic even at low concentrations to recipients (Rajeshkumar and Li, 2018). The working hypothesis of the study is that it is possible for cultured fish to accumulate heavy metals just like fish in the wild. Information arising from the study is expected to guide consumers of cultured fish particularly $H$. longifilis.

The heavy metal levels in $H$. longifilis have been referenced in line with the thresholds for heavy metals in fish published by the Food and Agriculture Organization of the United Nations (1983), Commission Regulation (2008) and CODEX Alimentarius (2015). For emphasis and clarity the stipulated thresholds for $\mathrm{Pb}, \mathrm{Cd}$, $\mathrm{Zn}$ and $\mathrm{Cu}$ in fish are $0.30 \mathrm{mg} / \mathrm{kg}, 0.10$ $\mathrm{mg} / \mathrm{kg}, \quad 40 \mathrm{mg} / \mathrm{kg}$ and $30 \mathrm{mg} / \mathrm{kg}$ respectively.

\section{MATERIALS AND METHODS}

\section{Study Area}

Warri town is located in Delta state, Nigeria and has geographic co-ordinates of Latitude $5^{\circ} 31^{\prime} \mathrm{N}$ and Longitude $5^{\circ} 45^{'} \mathrm{E}$. (Figure 1). 


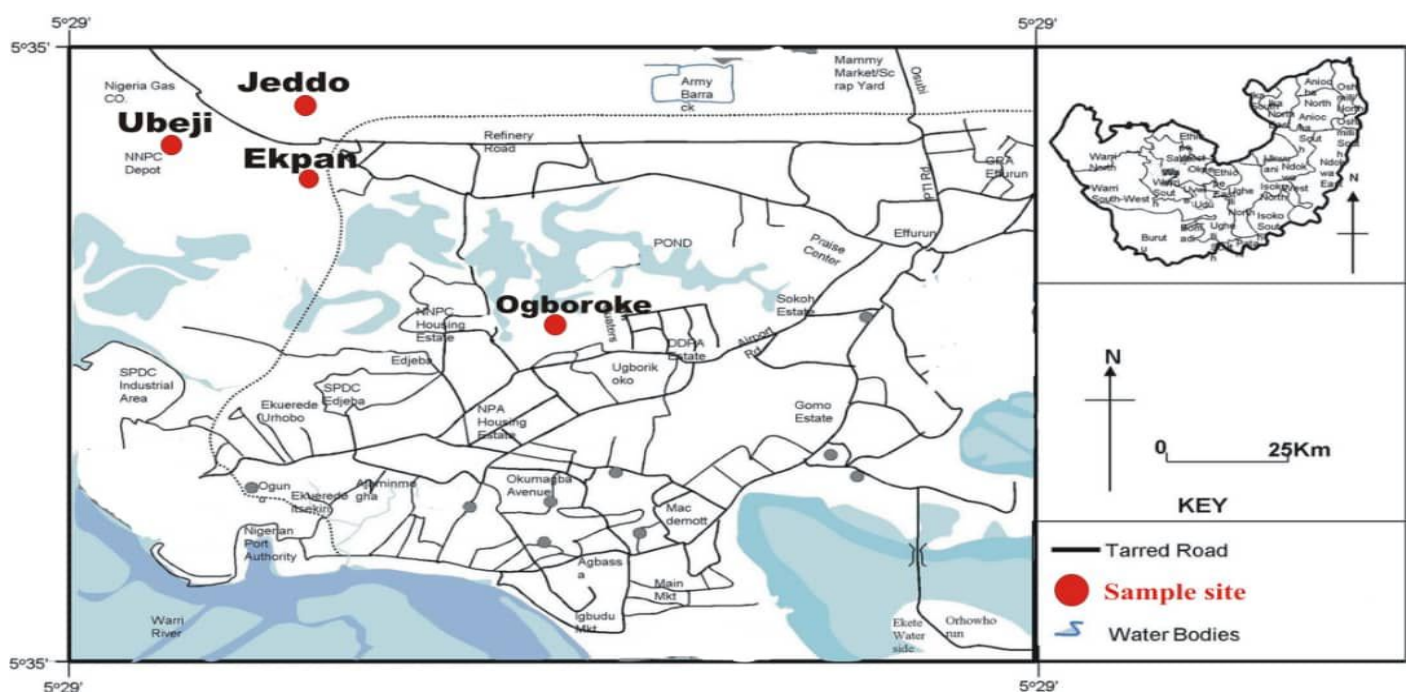

Figure 1. Study Area

It is a renowned hub for crude oil refining activities. Extensive details of the study area have previously been reported by Wangboje and Oghenesode (2017). The town has two distinct climatic seasons, namely, wet season (April-October) and dry season (November-March). Four communities namely, Oboroke, Ekpan, Ubeji and Jeddo, were purposely chosen for the study based on the availability of earthen ponds in these areas and levels of anthropogenic activities. Oboroke plays host to elementary schools, fishing activities, an oil servicing company and markets. Ekpan hosts the Warri refining and petrochemical company, a wood market, sawmill, Motor Park, elementary schools, markets, hotels and a general hospital. Ubeji and Jeddo both have markets, hospitals, elementary schools and petroleum tank farms. One pond from each of the aforesaid communities was selected for this pilot study based on available resources. Characteristics of the sampled earthen ponds are presented in Table 1.

Table 1. Characteristics of sampled earthen ponds

\begin{tabular}{|c|c|c|c|c|c|c|c|}
\hline Station & $\begin{array}{l}\text { Name of } \\
\text { cultured } \\
\text { species }\end{array}$ & $\begin{array}{l}\text { Number } \\
\text { sampled }\end{array}$ & $\begin{array}{l}\text { Mean } \\
\text { total } \\
\text { length of } \\
\text { fish }(\mathrm{cm})\end{array}$ & $\begin{array}{l}\text { Mean weight } \\
\text { of fish }(\mathrm{g})\end{array}$ & $\begin{array}{l}\text { Earthen } \\
\text { pond type }\end{array}$ & $\begin{array}{l}\text { Stocking } \\
\text { density } \\
\left(\text { Fish } / \mathrm{M}^{3}\right)\end{array}$ & $\begin{array}{l}\text { Artificial } \\
\text { feed }\end{array}$ \\
\hline Oboroke & $\begin{array}{l}H . \\
\text { longifilis }\end{array}$ & 12 & $\begin{array}{l}38.52 \pm \\
1.24\end{array}$ & $525.26 \pm 0.78$ & $\mathrm{Exc}$ & 18 & Coppens ${ }^{\circledR}$ \\
\hline Ekpan & $\begin{array}{l}\text { H. } \\
\text { longifilis }\end{array}$ & 12 & $\begin{array}{l}42.61 \pm \\
0.45\end{array}$ & $631.15 \pm 1.07$ & Excavated & 16 & Coppens ${ }^{\circledR}$ \\
\hline Ubeji & $\begin{array}{l}\text { H. } \\
\text { longifilis }\end{array}$ & 12 & $\begin{array}{l}41.73 \pm \\
0.57\end{array}$ & $552.27 \pm 0.98$ & Excavated & 25 & Coppens ${ }^{\circledR}$ \\
\hline Jeddo & $\begin{array}{l}H . \\
\text { longifilis }\end{array}$ & 12 & $\begin{array}{l}39.25 \pm \\
1.09\end{array}$ & $544.32 \pm 1.15$ & Excavated & 17 & Coppens ${ }^{\circledR}$ \\
\hline
\end{tabular}




\section{Collection of Fish and Water Samples}

Fish samples of seemingly similar size were netted from the earthen ponds after which they were washed with water from the pond to remove adhering debris and transported to the laboratory within 24 hours in a Thermolineo ${ }^{\circledR}$ ice chest. Surface water samples were collected in 1 Litre capacity polythene bottles with screw caps at approximately $30 \mathrm{~cm}$ depth. Water samples were acidified with $10 \%$ nitric acid to a $\mathrm{pH}$ of 1.5 , in order to keep metals in solution and to prevent them from adhering to the walls of the bottles as a standard practice. Water samples were transported to the laboratory within 24 hours on ice. The sampling campaign was carried out between January and June, 2018. Collection of both fish and water samples over months was done in order to identify the possibility of temporal variations. Water samples were used for bioaccumulation studies.

\section{Laboratory Procedures}

In the laboratory, the identities of the fish species were confirmed using taxonomic keys (Idodo-Umeh, 2003; Adesulu and Sydenham, 2007) and a field guide (Olaosebikan and Raji, 2013). They were weighed whole to the nearest gram using a Scout Pro SPU402 ${ }^{\circledR}$ electronic top loading scale while their total lengths were recorded to the nearest centimetre, using a measuring board. Myonematic tissues were excised with a stainless steel lancet from the flanks of fish specimens and oven dried at a temperature of $90^{\circ} \mathrm{C}$ for 48 hours in a Surgifield-Uniscope ${ }^{\circledR}$ (SM 9023 model) laboratory oven. Each dried sample was ground separately with a porcelain mortar and pestle and kept in labelled plastic vials with covers prior to digestion. Digestion was achieved following the method of Muiruri et al., (2013). The digest was stored in a $100 \mathrm{ml}$ plastic reagent bottle ready for Atomic absorption spectrophotometer (AAS) analysis. For the analysis of pond water, fifty (50) $\mathrm{ml}$ of water was measured into a $250 \mathrm{ml}$ conical flask. Twenty (20) $\mathrm{ml}$ of concentrated $\mathrm{HNO}_{3}$ was added and the mixture was heated $\left(80^{\circ} \mathrm{C}\right)$ over medium flame under a hood till the solution was reduced to $10 \mathrm{ml}$. The digest was transferred into a $250 \mathrm{ml}$ volumetric flask and made up to mark with distilled water. Each sample was stored in a sterile reagent bottle with a glass stopper prior to analysis. All digests were analysed for $\mathrm{Zn}, \mathrm{Pb}, \mathrm{Fe}, \mathrm{Cu}$ and $\mathrm{Cd}$ by means of an Atomic Absorption Spectrophotometer (Unicam ${ }^{\circledR} 969$ series) equipped with solar software using air acetylene flame as an oxidant. Concentrations of metals in fish and water were expressed in $\mathrm{mg} / \mathrm{kg}$ (wet weight) and $\mathrm{mg} / \mathrm{L}$ respectively, while Blanks, spiked samples, reference material analyses and duplicate analyses were performed for all analyses as part of the quality assurance procedures. All reagents used were of analytical grade (SIGMA, U.S.A.). Statistical software (GENSTAT ${ }^{\circledR}$ version 13.3 for Windows) was used for analysing generated data. Analysis of variance (ANOVA) was used to test for significant differences $(p<0.05)$ between mean values of heavy metals while Duncan Multiple Range Test was used to separate significant means. Microsoft Excel (for Windows 2010) was used for all graphical presentations.

\section{Bioaccumulation quotient (BQ)}

The Bioaccumulation Quotient (BQ) or Bioaccumulation factor for heavy metals in fish was ascertained using the method by Eikenberry et al., (2015).

\section{Heavy metal level in fish \\ Heavy metal level in water}

\section{Hazard Quotient (HQ) for Heavy Metals}

The hazard quotient (HQ) for chemical elements is a comparison of the measured concentration of site-related elements in 
ecological matrices with specific healthbased criteria (Newstead et al., 2002).

$\mathrm{HQ}=\frac{\text { Concentration of heavy metal in fish sample }}{\text { Health based criteria }}$

\section{Maximum acceptable risk index (MAR) for heavy metals}

The maximum acceptable risk index (MAR), is a simplified representation of bio magnifications in food webs (Reinhold et al., 1999).

Where: MAR $>1=$ High MAR level and MAR $<1=$ Low MAR level.

\section{Estimated Average Daily Intake (EADI) of Heavy Metals by Man}

The EADI was obtained by multiplying the mean heavy metal content in fish $(\mathrm{mg} / \mathrm{kg})$ by the per capita fish consumption of an area $(0.04 \mathrm{~kg} / \mathrm{person} /$ day in the Niger Delta) and dividing the product by the typical human adult body weight, estimated to be $70 \mathrm{~kg}$ (Ezemonye et al., 2017).

\section{RESULTS}

\section{Concentrations of heavy metals in water}

Table 2. Mean concentrations $(\mathrm{mg} / \mathrm{L})$ of heavy metals in water by month

\begin{tabular}{lllll}
\hline Month & $\mathrm{Cd}$ & $\mathrm{Cu}$ & $\mathrm{Pb}$ & $\mathrm{Zn}$ \\
\hline January & $0.23 \pm 0.11^{\mathrm{b}}$ & $1.72 \pm 0.28^{\mathrm{c}}$ & $1.27 \pm 1.49^{\mathrm{a}}$ & $0.89 \pm 0.65^{\mathrm{c}}$ \\
February & $0.29 \pm 0.13^{\mathrm{a}}$ & $1.34 \pm 0.38^{\mathrm{c}}$ & $0.21 \pm 0.13^{\mathrm{b}}$ & $0.41 \pm 0.22^{\mathrm{c}}$ \\
March & $0.21 \pm 0.03^{\mathrm{b}}$ & $3.04 \pm 2.33^{\mathrm{a}}$ & $0.02 \pm 0.01^{\mathrm{c}}$ & $1.32 \pm 1.04^{\mathrm{b}}$ \\
April & $0.26 \pm 0.17^{\mathrm{a}}$ & $1.48 \pm 0.39^{\mathrm{c}}$ & $0.06 \pm 0.04^{\mathrm{c}}$ & $1.39 \pm 1.10^{\mathrm{b}}$ \\
May & $0.19 \pm 0.19^{\mathrm{b}}$ & $3.56 \pm 3.95^{\mathrm{a}}$ & $0.09 \pm 0.06^{\mathrm{c}}$ & $1.18 \pm 1.23^{\mathrm{b}}$ \\
June & $0.42 \pm 0.42^{\mathrm{a}}$ & $2.56 \pm 0.64^{\mathrm{b}}$ & $0.17 \pm 0.12^{\mathrm{b}}$ & $2.68 \pm 2.18^{\mathrm{a}}$ \\
SEM & 0.08 & 1.34 & 0.72 & 0.87 \\
*Pond Threshold & 0.05 & 0.02 & 0.1 & 1.0 \\
\hline
\end{tabular}

Columns with similar letters are not significantly different $(\mathrm{p}>0.05)$. Schneider (1971)

Table 3. Mean concentrations $(\mathrm{mg} / \mathrm{L})$ of heavy metals in water by station

\begin{tabular}{lllll}
\hline Station & $\mathrm{Cd}$ & $\mathrm{Cu}$ & $\mathrm{Pb}$ & $\mathrm{Zn}$ \\
\hline Oboroke & $0.22 \pm 0.08^{\mathrm{a}}$ & $1.76 \pm 0.74^{\mathrm{b}}$ & $0.91 \pm 2.01^{\mathrm{a}}$ & $0.57 \pm 0.51^{\mathrm{b}}$ \\
Ekpan & $0.27 \pm 0.12^{\mathrm{a}}$ & $1.89 \pm 1.89^{\mathrm{b}}$ & $0.07 \pm 0.05^{\mathrm{b}}$ & $1.18 \pm 1.38^{\mathrm{b}}$ \\
Ubeji & $0.31 \pm 0.18^{\mathrm{a}}$ & $3.47 \pm 3.37^{\mathrm{a}}$ & $0.08 \pm 0.06^{\mathrm{b}}$ & $2.17 \pm 1.62^{\mathrm{a}}$ \\
Jeddo & $0.24 \pm 0.08^{\mathrm{a}}$ & $1.98 \pm 1.24^{\mathrm{b}}$ & $0.17 \pm 0.16^{\mathrm{b}}$ & $1.32 \pm 1.21^{\mathrm{b}}$ \\
SEM & 0.08 & 1.08 & 0.58 & 0.72 \\
Pond Threshold & 0.05 & 0.02 & 0.1 & 1.0 \\
\hline
\end{tabular}

Columns with similar letters are not significantly different $(p>0.05)$ 


\section{Concentrations of Heavy Metals in $\boldsymbol{H}$. longifilis}

As presented in Table 4, the mean concentrations of metals in $H$. longifilis by month, ranged from $0.13 \mathrm{mg} / \mathrm{kg}$ for $\mathrm{Cd}$ in January to $72.51 \mathrm{mg} / \mathrm{kg}$ for $\mathrm{Cu}$ in June with significant differences $(\mathrm{p}<0.05)$ observed in the mean concentrations of $\mathrm{Cu}, \mathrm{Pb}$ and $\mathrm{Zn}$ in fish between months. As shown in Table 5 , the mean concentrations of metals in $H$. longifilis by station, ranged from $0.12 \mathrm{mg} / \mathrm{kg}$ for $\mathrm{Cd}$ at Jeddo to $69.27 \mathrm{mg} / \mathrm{kg}$ for $\mathrm{Cu}$ at Ubeji with significant differences $(p<0.05)$ observed in the mean concentration of $\mathrm{Zn}$ in fish between stations.

Table 4. Mean concentrations $(\mathrm{mg} / \mathrm{kg})$ of heavy metals in Heterobranchus longifilis by month

\begin{tabular}{lllll}
\hline Month & $\mathrm{Cd}$ & $\mathrm{Cu}$ & $\mathrm{Pb}$ & $\mathrm{Zn}$ \\
\hline January & $0.13 \pm 0.05^{\mathrm{a}}$ & $52.08 \pm 19.95^{\mathrm{b}}$ & $3.24 \pm 2.13^{\mathrm{a}}$ & $57.82 \pm 32.15^{\mathrm{a}}$ \\
February & $0.17 \pm 0.08^{\mathrm{a}}$ & $55.03 \pm 11.17^{\mathrm{b}}$ & $0.55 \pm 0.26^{\mathrm{b}}$ & $7.51 \pm 4.69^{\mathrm{b}}$ \\
March & $0.16 \pm 0.05^{\mathrm{a}}$ & $65.75 \pm 8.77^{\mathrm{a}}$ & $0.45 \pm 0.29^{\mathrm{b}}$ & $6.25 \pm 1.31^{\mathrm{b}}$ \\
April & $0.17 \pm 0.08^{\mathrm{a}}$ & $62.55 \pm 2.48^{\mathrm{a}}$ & $0.37 \pm 0.23^{\mathrm{b}}$ & $6.85 \pm 1.56^{\mathrm{b}}$ \\
May & $0.17 \pm 0.15^{\mathrm{a}}$ & $71.58 \pm 6.44^{\mathrm{a}}$ & $0.73 \pm 0.34^{\mathrm{b}}$ & $7.71 \pm 1.91^{\mathrm{b}}$ \\
June & $0.15 \pm 0.14^{\mathrm{a}}$ & $72.51 \pm 10.68^{\mathrm{a}}$ & $0.85 \pm 0.71^{\mathrm{b}}$ & $8.53 \pm 0.62^{\mathrm{b}}$ \\
SEM & 0.05 & 7.97 & 0.67 & 9.42 \\
Threshold & $0.10^{*}$ & $30^{* *}$ & $0.30^{* * *}$ & $40^{* *}$ \\
\hline
\end{tabular}

Columns with similar letters are not significantly different $(\mathrm{p}>0.05) *$ Commission Regulation $(2008) * *$ FAO (1983) *** CODEX Alimentarius (2015)

Table 5. Mean concentrations (mg/kg) of heavy metals in Heterobranchus longifilis by station

\begin{tabular}{lllll}
\hline Station & $\mathrm{Cd}$ & $\mathrm{Cu}$ & $\mathrm{Pb}$ & $\mathrm{Zn}$ \\
\hline Oboroke & $0.15 \pm 0.05^{\mathrm{a}}$ & $65.55 \pm 12.42^{\mathrm{a}}$ & $0.66 \pm 0.34^{\mathrm{a}}$ & $13.48 \pm 11.15^{\mathrm{b}}$ \\
Ekpan & $0.16 \pm 0.07^{\mathrm{a}}$ & $58.92 \pm 9.47^{\mathrm{a}}$ & $1.18 \pm 1.91^{\mathrm{a}}$ & $23.07 \pm 40.34^{\mathrm{a}}$ \\
Ubeji & $0.18 \pm 0.07^{\mathrm{a}}$ & $69.27 \pm 12.29^{\mathrm{a}}$ & $1.36 \pm 1.78^{\mathrm{a}}$ & $13.81 \pm 16.96^{\mathrm{b}}$ \\
Jeddo & $0.12 \pm 0.04^{\mathrm{a}}$ & $59.25 \pm 15.93^{\mathrm{a}}$ & $0.93 \pm 0.56^{\mathrm{a}}$ & $12.73 \pm 14.43^{\mathrm{b}}$ \\
SEM & 0.03 & 7.35 & 0.81 & 132.71 \\
Threshold & 0.10 & 30 & 0.30 & 40 \\
\hline
\end{tabular}

Columns with similar letters are not significantly different $(\mathrm{p}>0.05)$

The Bioaccumulation quotient (BQ) values for metals in fish ranged from 0.50 for $\mathrm{Cd}$ at Jeddo to 37.24 for $\mathrm{Cu}$ at Oboroke (Figure 2) while the Hazard quotient (HQ) for metals ranged from 0.39 for $\mathrm{Zn}$ to 3.43 for $\mathrm{Pb}$ as shown in Figure 3. The Maximum acceptable risk (MAR) values for metals in fish ranged from 0.02 for $\mathrm{Pb}$ at Ekpan to 6.29 for $\mathrm{Zn}$ at Ubeji (Figure 4) while the Estimated average daily intake (EADI) of heavy metals ranged from 0.09 $\mathrm{mg} /$ person/day for $\mathrm{Cd}$ to 36.13 $\mathrm{mg} /$ person/day for $\mathrm{Cu}$ as presented in Figure 5. As presented in Figure 6, the total heavy metal load in $H$. longifilis by station ranged from $73.03 \mathrm{mg} / \mathrm{kg}$ at Jeddo to 84.62 $\mathrm{mg} / \mathrm{kg}$ at Ubeji while the heavy metal quota peaked at $78.86 \%$ and $59.53 \%$ for $\mathrm{Cu}$ in fish and water respectively (Figure 7). The condition factor for fish ranged from 0.30 at Jeddo to 0.92 at Oboroke (Figure 8). 


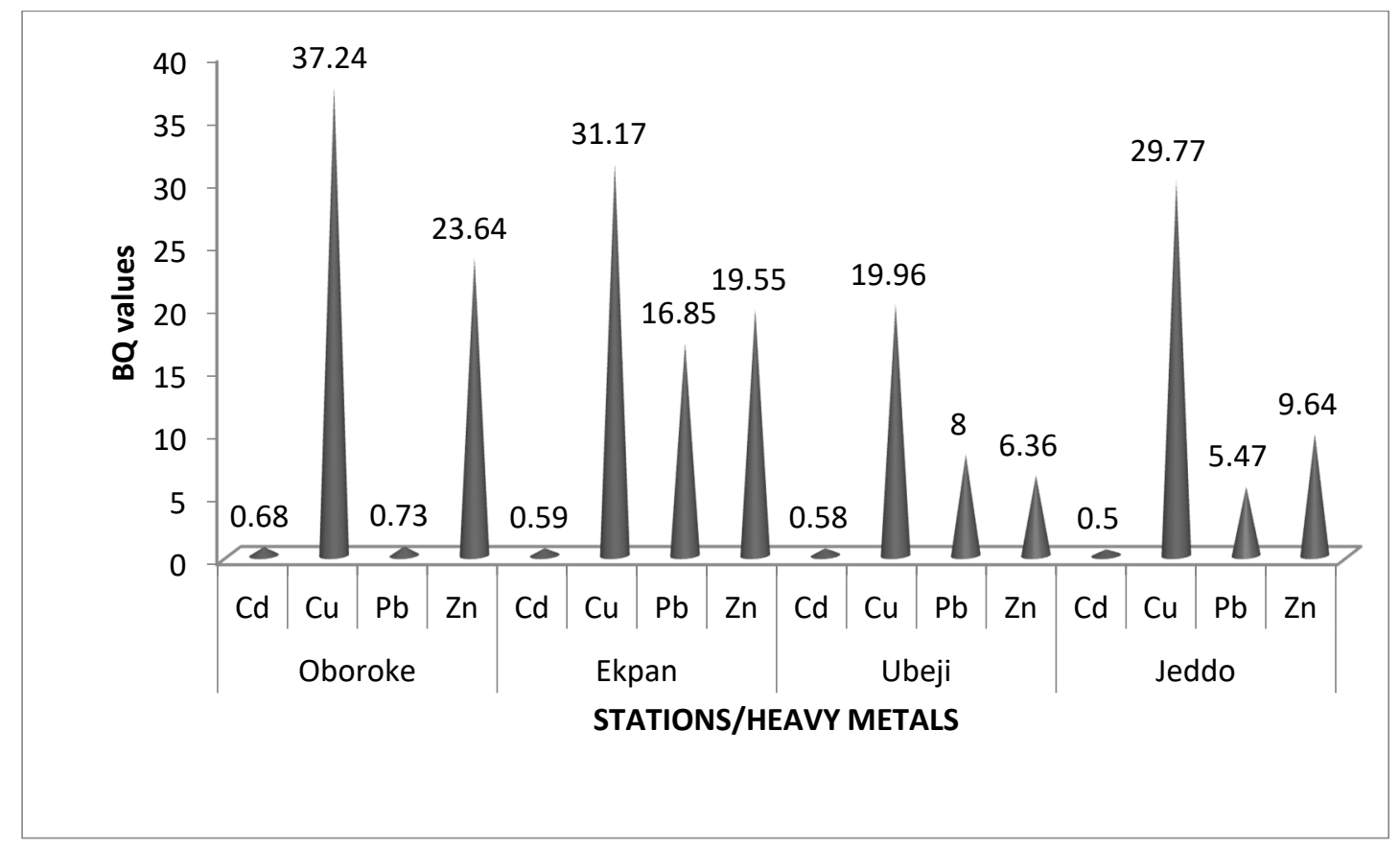

Figure 2. Bioaccumulation quotient (BQ) for heavy metals in Heterobranchus longifilis

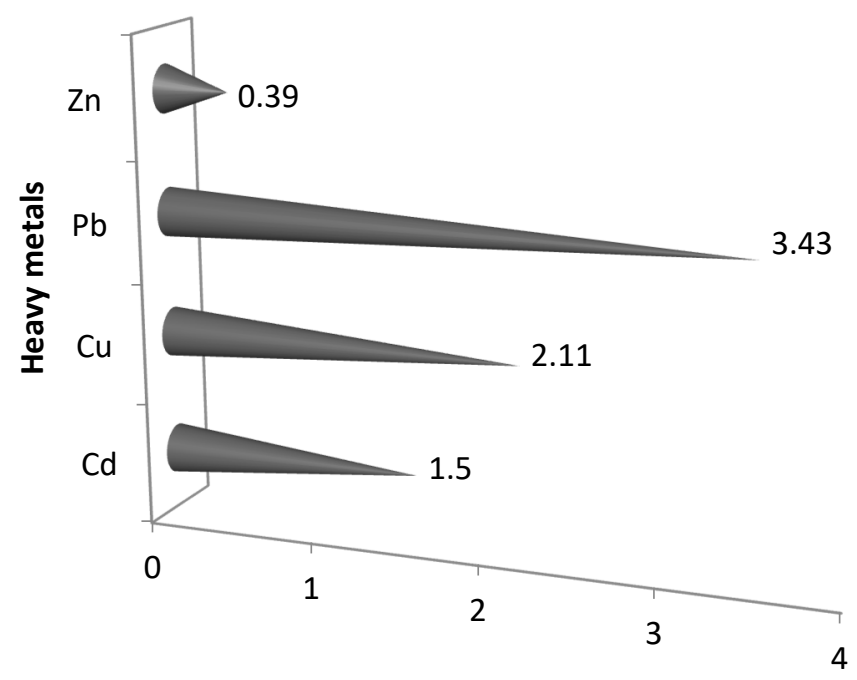

HQ values

Figure 3. Hazard quotient (HQ) values for heavy metals in Heterobranchus longifilis 


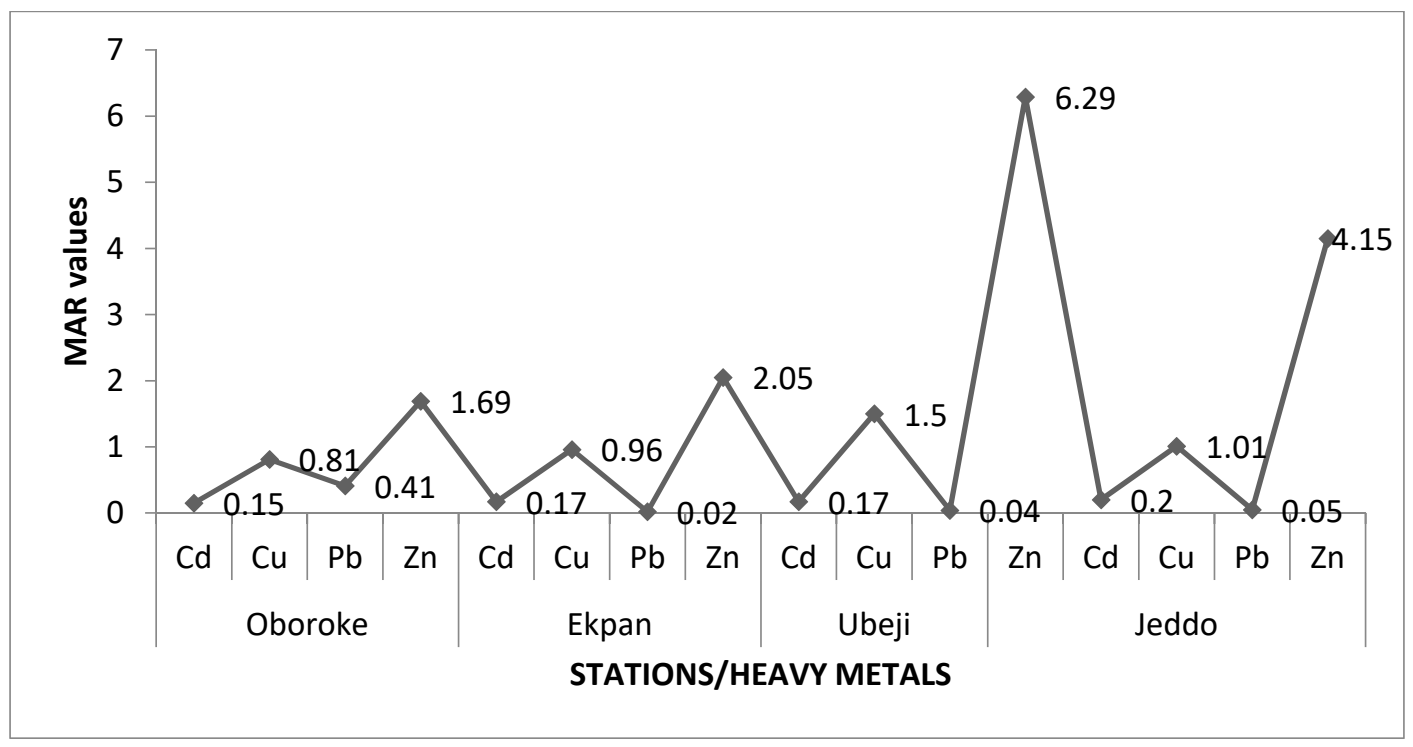

Figure 4. Maximum acceptable risk (MAR) values for heavy metals in Heterobranchus longifilis

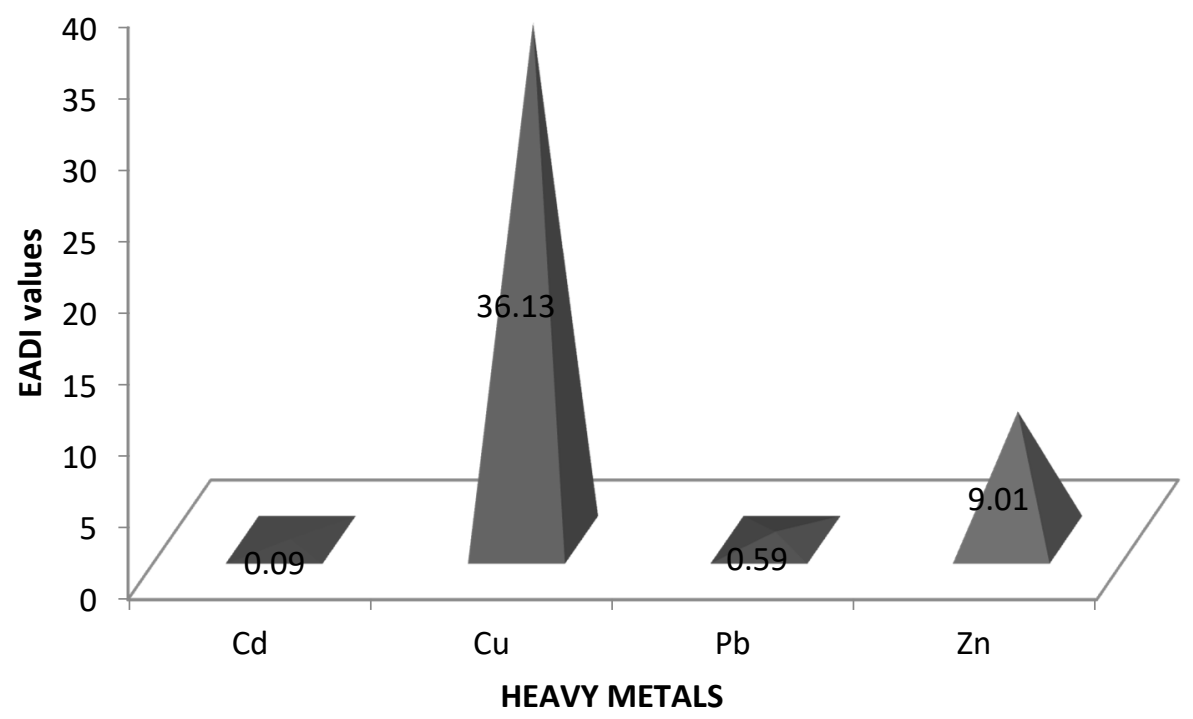

Figure 5. Estimated average daily intake (EADI) for heavy metals 


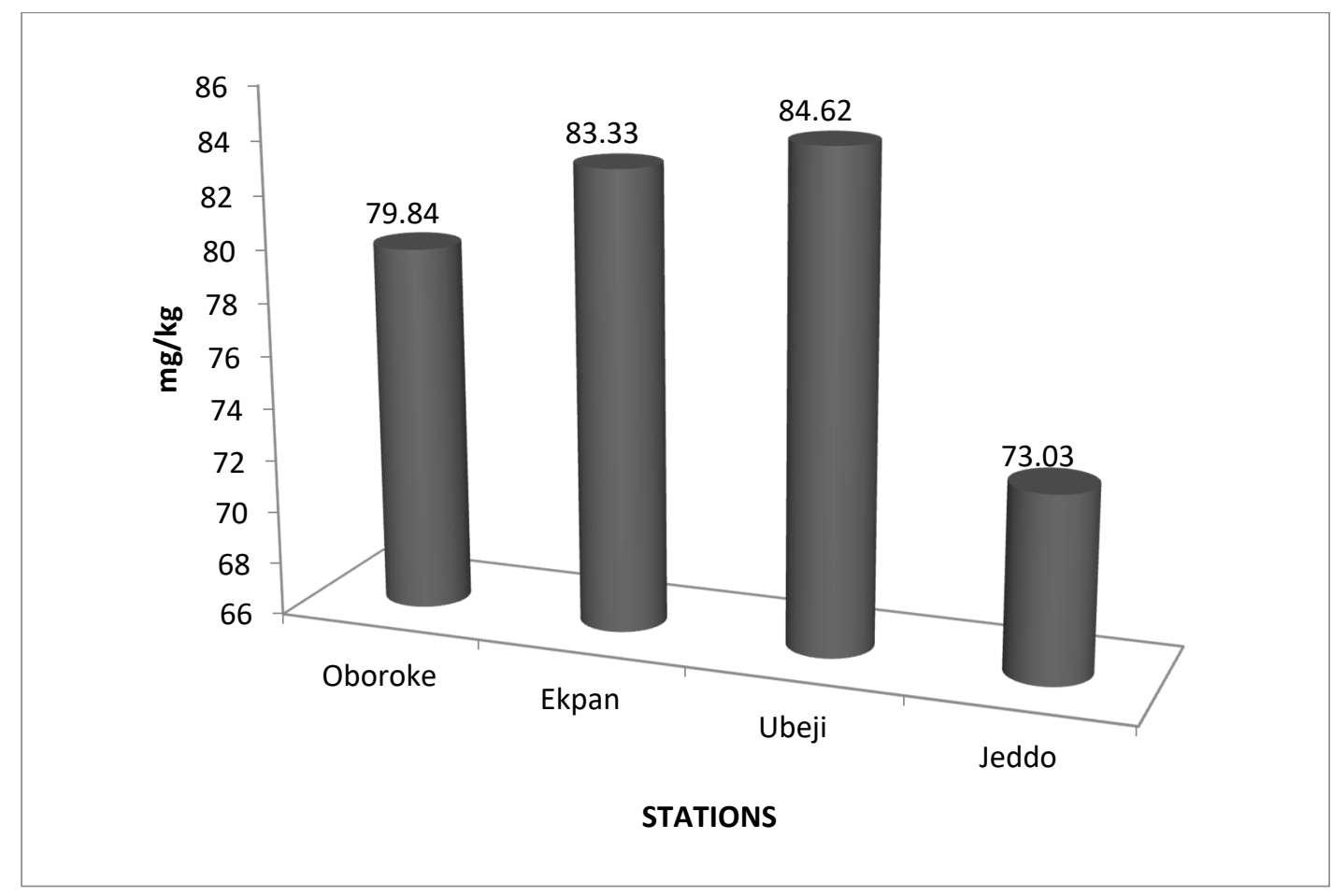

Figure 6. Total heavy metal load in Heterobranchus longifilis by station

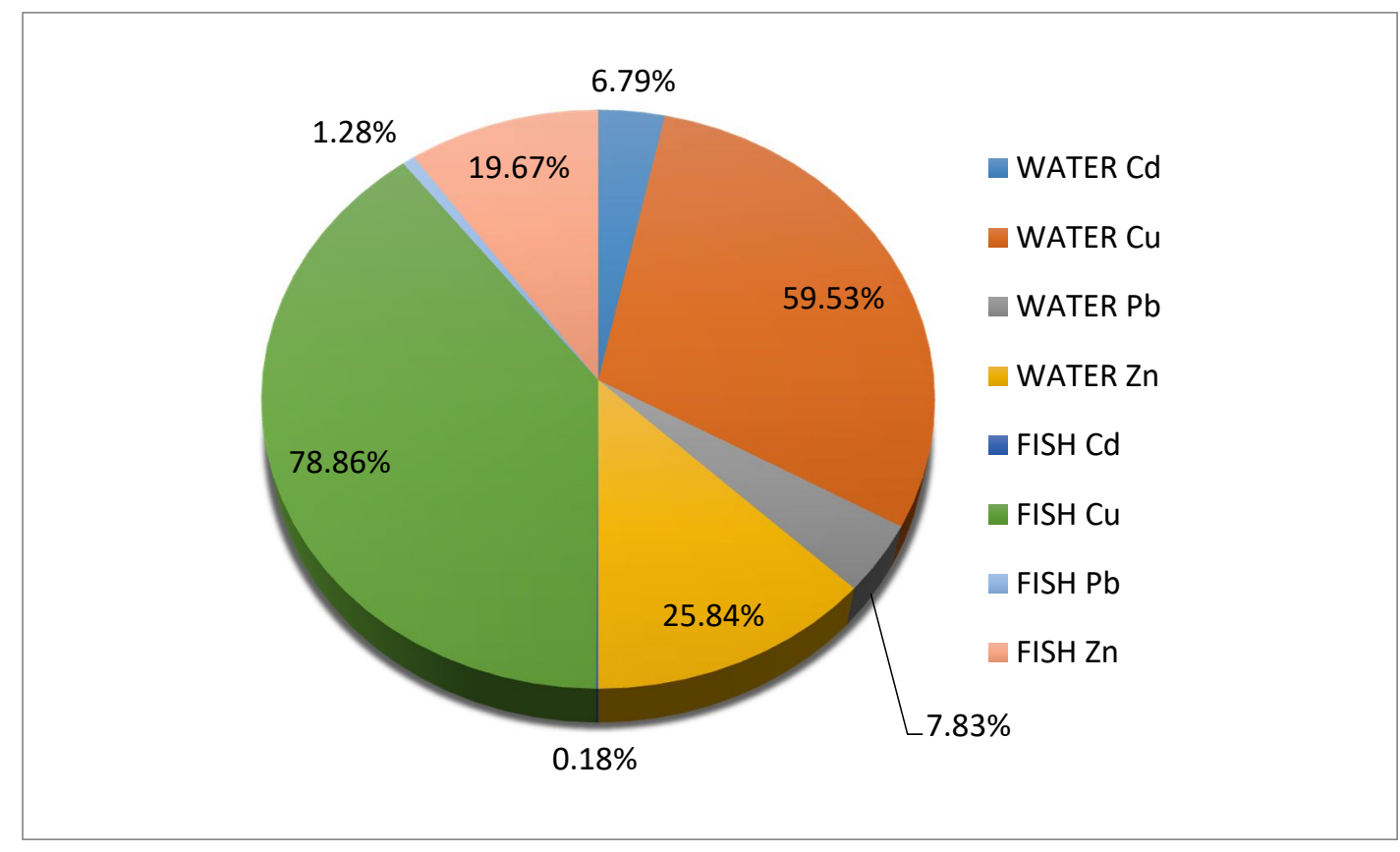

Figure 7. Heavy metal quota in water and fish for the study period 


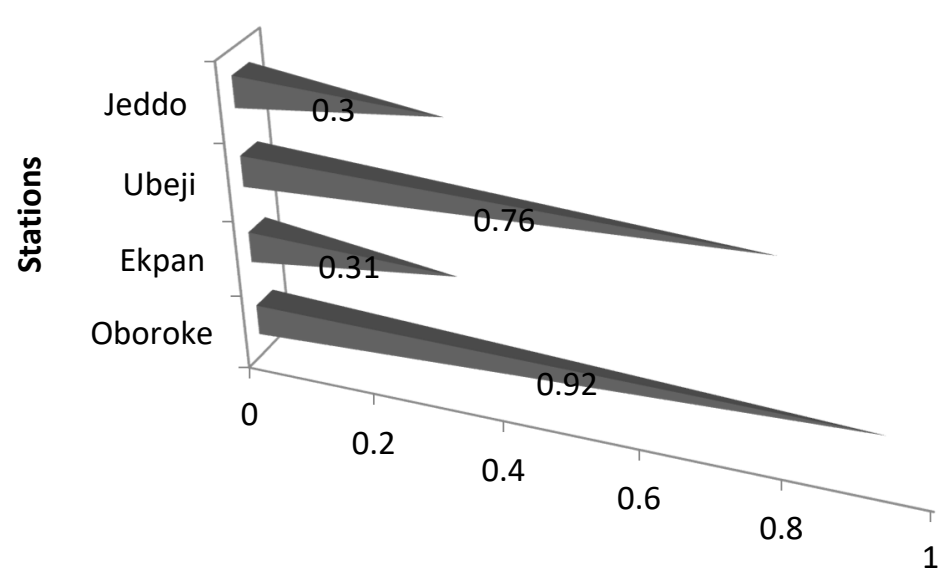

Condition factor

Figure 8. Condition factor for fish by station

\section{DISCUSSION}

It was observed that the mean concentrations of heavy metals in $H$. longifilis in the examined earthen ponds took the general order $\mathrm{Cu}>\mathrm{Zn}>\mathrm{Pb}>\mathrm{Cd}$, indicating that $\mathrm{Cu}$ was readily more bioavailable to the fish than the other metals while $\mathrm{Cd}$ was the least in terms of bioavailability. The heavy metal quota in water and consequently in fish, further gives a graphic representation of this observation. In addition, this observation was supported by the BQ values for metals in fish, which was the highest and lowest for $\mathrm{Cu}$ and $\mathrm{Cd}$ respectively. Generally, $\mathrm{Cd}$ was the only metal not bio accumulated by fish. This observation can be attributed to the fact that $\mathrm{Cd}$ had the least mean concentration in water compared to the other metals and therefore was not readily available to fish. It could also mean that the metal was speedily metabolized by fish so that bioaccumulation was nil. According to Aldoghachi et al., (2016), heavy metals that are not metabolized in the body of fish become toxic and will accumulate in soft tissues. Levels of metals in fish are known to be influenced by growth rate, metabolism, feeding patterns and ecological requirements of individual fish species (Ibrahim et al., 2018). According to the Australian and New Zealand guidelines for fresh and marine water quality, metal bioaccumulation by fish can be influenced by $\mathrm{pH}$, kinetics of uptake, depuration time, redox status in the gut, concentration and chemical speciation of the metal as well as the ability of fish to internally regulate metal concentrations or inactivate effects of accumulated metals (ANZECC/ARMCANZ, 2000). Apart from $\mathrm{Zn}$, there were no significant differences $(p>0.05)$ in the mean concentrations of the metals in fish between stations, giving an indication of the relative steady or uniform status of these metals to fish during the duration of the study. It was observed that the mean concentrations of $\mathrm{Cd}, \mathrm{Cu}$ and $\mathrm{Pb}$ in fish were highest at Ubeji station, clearly suggesting a higher dose of these metals at this station compared to the other stations while the mean concentrations of $\mathrm{Cd}$ and $\mathrm{Zn}$ in fish were lowest at Jeddo station. In addition, the total heavy metal load in fish was at a peak at Ubeji and was the least at Jeddo, 
suggesting a conceivably higher impact of metals at the former station. It is logical to categorically state that runoff from the petroleum tank farm at Ubeji could be contributing to the high levels of metals in the earthen pond at this point. This assertion is made within the framework that runoff from the tank farm could conceivably reach the earthen pond, making the depot a potential point source of contamination. This assertion is buttressed by the fact that refined petroleum products typically contain heavy metals such as $\mathrm{Pb}$, $\mathrm{Cd}, \mathrm{Cr}, \mathrm{Cu}, \mathrm{Ni}, \mathrm{Fe}$ and $\mathrm{Zn}$ (Oketola et al., 2013; Akpoveta and Osakwe, 2014). Similarly, the highest mean concentration of $\mathrm{Zn}$ in fish was observed at Ekpan. The refining and petrochemical company at Ekpan could be linked to the high levels of $\mathrm{Zn}$ in fish. This deduction is made on the premise that refineries are known sources of heavy metals especially $\mathrm{Ni}, \mathrm{Zn}, \mathrm{V}, \mathrm{Pb}, \mathrm{Fe}$ and Mn (Calamari and Naeve, 1994). Generally adjoining roads, farms, landscapes and the atmosphere have been recognized as non-point sources of pond water contamination (Brown and Froemke, 2012). Significant differences $(p<0.05)$ were observed in the mean concentrations of $\mathrm{Cu}$, $\mathrm{Pb}$ and $\mathrm{Zn}$ in fish between months, giving an indication of seasonal variation in the dynamics of the metals in fish between months. For example, the peak concentrations of $\mathrm{Cd}, \mathrm{Pb}$ and $\mathrm{Zn}$ in fish were recorded within the dry season while the peak concentration of $\mathrm{Cu}$ in fish was recorded in the wet season. Furthermore, the lowest concentrations of $\mathrm{Cd}, \mathrm{Cu}, \mathrm{Pb}$ and $\mathrm{Zn}$ in fish were recorded in the dry season. In order to fully understand the dynamics of heavy metals in the pond system, it may be necessary to analyse the pond soil or sediment, which can serve as a repository for metals. Water samples could also be collected from both upstream and downstream points while data could be collected over a longer period such as a year or two in order to make more profound assertions and deductions. Health-wise, the mean concentrations of $\mathrm{Cd}, \mathrm{Cu}$ and $\mathrm{Pb}$ in fish exceeded established International thresholds of $0.10 \mathrm{mg} / \mathrm{kg}, 30 \mathrm{mg} / \mathrm{kg}$ and $0.30 \mathrm{mg} / \mathrm{kg}$ respectively for these metals in fish. For example, the mean concentration of $\mathrm{Cd}$ in fish was one and a half times over its limit while $\mathrm{Cu}$ and $\mathrm{Pb}$ were twice and thrice over their respective limits. This observation clearly indicates the unfitness of such fish for prolonged consumption by man. In this study, the applied thresholds for metals in fish were Food and Agricultural Organization of the United Nations (FAO, 1983), Commission Regulation (2008) and CODEX Alimentarius (2015). The mean concentrations of $\mathrm{Cd}(0.19 \mathrm{mg} / \mathrm{kg}), \mathrm{Pb}(3.31$ $\mathrm{mg} / \mathrm{kg})$ and $\mathrm{Zn}(21.71 \mathrm{mg} / \mathrm{kg})$ in a similar catfish (Pseudoplatystoma corruscans) from the Paraopeba River in Brazil (Arantes et al., 2016) were much higher than the corresponding metals in fish in this study. The workers apportioned the contamination of fish to the receipt of effluents from electroplating and steel industries in the vicinity. The extremely high mean value of $\mathrm{Zn}(60 \mathrm{mg} / \mathrm{kg})$ recorded for Mastacembelus armatus by Ashraf et al., (2012) from a pond in Bestari Jaya, Malaysia, quadrupled the mean concentration of $\mathrm{Zn}$ found in fish in this study. The workers attributed the high level of $\mathrm{Zn}$ and other detected metals to the influx of effluents from a former tin mining zone. The mean concentrations of $\mathrm{Cu}(0.54 \mathrm{mg} / \mathrm{kg})$ and $\mathrm{Cd}$ $(0.06 \mathrm{mg} / \mathrm{kg})$ observed in Clarias gariepinus (African sharp tooth catfish) from Lake Njuwa, Adamawa state, Nigeria by Ibrahim et al., (2018), were far less than the mean concentrations of the same metals in fish in this study, suggesting a much higher interaction between fish and these metals in this study. In water, the general rank profile of heavy metals was $\mathrm{Cu}>\mathrm{Zn}>\mathrm{Pb}>\mathrm{Cd}$, giving an indication of a dominant presence of $\mathrm{Cu}$ and its associated compounds in water. Station-wise, $\mathrm{Cu}$ had the highest 
mean concentration in water at all the stations, closely followed by $\mathrm{Zn}$, with $\mathrm{Cd}$ and $\mathrm{Pb}$ interchanging tail positions. There were significant differences $(\mathrm{p}<0.05)$ in the mean concentrations of $\mathrm{Cu}, \mathrm{Pb}$ and $\mathrm{Zn}$ in water between stations, suggesting a clear variation in the influx of these metals into water at the various stations. For example, the highest mean concentrations of $\mathrm{Cd}, \mathrm{Cu}$ and $\mathrm{Zn}$ in water were observed at Ubeji station while the lowest mean concentrations of the same metals in water were observed at Oboroke station. There were significant differences $(\mathrm{p}<0.05)$ in the mean concentrations of heavy metals in water between months, suggesting once again the effects of seasonal variation. For example, the peak concentrations of $75 \%$ of the metals (i.e. $\mathrm{Cd}, \mathrm{Cu}$ and $\mathrm{Zn}$ ) in water were observed in the wet season while the least concentrations of all the metals in water occurred in the dry season. This observation highlights the possible effects of rainfall and consequent runoff on the input of metals into the pond system. As supported by Ayeni and Balogun (2012), the quality of pond water can be influenced by the level of contamination from effluents from adjoining land and runoff. Regarding the health status of fish, with emphasis on heavy metals, the mean concentrations of $\mathrm{Cd}, \mathrm{Cu}$ and $\mathrm{Pb}$ in water exceeded the established metal threshold for freshwater fish in ponds. For example the mean concentrations of $\mathrm{Cd}, \mathrm{Cu}$ and $\mathrm{Pb}$ in water were five times, a hundred fold and thrice their respective metal limits of $0.05 \mathrm{mg} / \mathrm{L}, 0.02 \mathrm{mg} / \mathrm{L}$ and $0.1 \mathrm{mg} / \mathrm{L}$ respectively, clearly indicating an obvious potential threat to the wellbeing of these fishes in their aquatic media. Schneider (1971) compiled a comprehensive list of thresholds for various heavy metals in freshwater ponds which was applied in this study. The condition factor revealed that all the sampled fishes were poorly conditioned in their respective ponds although fish at Oboroke almost attained unity. The general poor condition factors may be linked to the impact of heavy metals, although other xenobiotics may also be responsible. This assertion is based on the fact that contaminants do not always act alone in natural environments but rather present as a cocktail of compounds acting in tandem. According to Akbar et al., (2017), heavy metals can produce toxic effects in fish and also reduce their overall growth rate. Mortality is to be expected owing to extreme and prolonged exposure. It also pertinent to note that the condition factor may also be influenced by the availability of suitable food for fish as corroborated by Wangboje and Ikhuabe (2015). It was observed that all ponds were in receipt of the same commercial branded food (Coppens ${ }^{\circledR}$ ) although stocking densities differed. Ovie $e t$ al., (2008), observed that stocking densities may affect condition factors and that the ideal stocking density for $H$. longifilis in tanks is $10 \mathrm{fish} / \mathrm{M}^{3}$. However the stocking densities in this study ranged from 16 fish/ $\mathrm{M}^{3}$ at Ekpan to 25 fish $/ \mathrm{M}^{3}$ at Ubeji. The EADI values for heavy metals followed a rank profile of $\mathrm{Cu}>\mathrm{Zn}>\mathrm{Pb}>\mathrm{Cd}$ which was the same order for metals in fish. According to Wangboje and Miller (2018), the direction in which the EADI values would follow is determined by the heavy metal levels in fish. It becomes clear that potential consumers of such fish would be exposed to more of $\mathrm{Cu}$ and less of $\mathrm{Cd}$. The MAR values observed in this study indicate that $\mathrm{Zn}$ is the metal that has the highest tendency to biomagnify in man, closely followed by $\mathrm{Cu}$, as unity was surpassed for both MAR values. The HQ values which evaluate non-carcinogenic risk revealed that $\mathrm{Cd}, \mathrm{Cu}$ and $\mathrm{Pb}$ were the metals that present a risk to the consuming public as unity was surpassed. According to Maurya and Malik (2018), these heavy metals are known to cause different forms of cancers, kidney damage and mental retardation respectively. Furthermore, the adverse effects of $\mathrm{Cd}$ on meterno-fetal subjects have been documented (Espart et al., 2018). 


\section{CONCLUSION}

The bifurcated objectives of this research were successfully achieved. The study provided baseline data for some heavy metals in $H$. longifilis cultured in earthen ponds in Warri town, Nigeria, which could serve as a reference point for future studies. Furthermore, it was revealed that the mean concentrations of $\mathrm{Cd}, \mathrm{Cu}$ and $\mathrm{Pb}$ in $H$. longifilis surpassed established International thresholds for these metals in fish indicating the unfitness of such fish for prolonged consumption by man. The aforesaid metals were also shown to be a potential threat to the health of $H$. longifilis in the earthen ponds. Following the outcome of the study, it becomes mandatory for the heavy metal content in these earthen ponds to be routinely monitored in order to keep metal levels within safe limits. Furthermore, it is proffered that heavy metals not included in this research be incorporated in future studies in order to extend the metal repository for the study area.

\section{ACKNOWLEDGEMENT}

We wish to thank Martlet Environmental Laboratory, Benin City, Nigeria, for the use of their Atomic Absorption Spectrometric facility.

\section{REFERENCES}

Adesulu, E. A. and Sydenham, D. H. J. 2007. The Freshwater fishes and fisheries of Nigeria. McMillan Nigeria Limited, Ibadan, Nigeria. 397 pp.

Akbar, A., Siddique, A. and Kanwal, Q. 2017. Growth performance of Catla catla fish in earthen pond under metal stressed conditions. Bulletin of Environmental Studies, 2(1):23-28.

Akoma, O.C. and Uhunmwango, O.S. 2017. Quantitative estimation of pollution in groundwater and surface water in Benin and environs. Ethiopian Journal of Environmental Studies and Management,
10(3):

$340-350$.

doi.org/10.4314/ejesm.v10i3.5

Akpoveta, O.V. and Osakwe, S.A. 2014. Determination of heavy metal content in refined petroleum products. IOSR Journal of Applied Chemistry, 7(6): 1-2.

Aldoghachi, M.A.J., Rahman, M.M.A., Yusoff, I., Sofian-Azirun, M. 2016. Acute toxicity and bioaccumulation of heavy metals in red Tilapia fish. The Journal of Animal and Plant Sciences, 26(2): 507-513.

ANZECC/ARMCANZ. 2000. Australian and New Zealand guidelines for fresh and marine water quality Vol. 1: National Water Quality Management Strategy, Paper No. 4. Australian and New Zealand Environment and Conservation Council/Agriculture and Resource Management Council of Australia and New Zealand, Canberra, Australia.

Arantes, F.P., Savassi, L.A., Santos, H.B., Gomes, M.V.T. and Bazzoli, N. 2016. Bioaccumulation of mercury, cadmium, zinc, chromium, and lead in muscle, liver and spleen tissues of a large commercially valuable catfish species from Brazil. Annals of the Brazilian Academy of Sciences, doi.org/10.1590/00013765201620140434.

Ashraf, M.A., Maah, M. J. and Yusoff, I. 2012. Bioaccumulation of heavy metals in fish species collected from former tin mining catchment. International Journal of Environmental Research, 6(1):209-218.

Ayeni, A.O. and Balogun, I.I. 2012. Evaluation and performance of heavy metals in surface ponds among land-use using Z-score and coefficient of variation. Asian Journal of Scientific Research, 5(3): http://doi.org/10.3923/ajsr.2012.162.16 9

Bluwey, F.A., Taiwo, I.O., Okonji, V.A., Kumah, L.A., Ipinmoroti, M.O., Boateng, M.A. and Idoko, F.A. 2018. Introduction to Fisheries of West Africa. 
Volume 1. Root and Associates Publishers, Benin City, Nigeria. 193 pp.

Brown, T.C. and Froemke, P. 2012. Nationwide assessment of nonpoint source threats to water quality. Bioscience, 62(2):

136-146. http://doi.org/10.1525/bio.2012.62.2.7

Calamari, D. and Naeve, H. 1994. Review of pollution in the African aquatic environment. Committee for Inland Fisheries of Africa (CIFA), Technical Paper No. 25, FAO, Rome. 118 pp.

Codex Alimentarius. 2015. General standards for contaminants and toxins in food and feed. 2015 Amendment, (CODEX STAN 193-1995). International Food Standards. FAO/WHO. 2015 Amendment. 59 pp.

Commission Regulation. 2008. Setting maximum levels for certain contaminants in foodstuffs. Commission Regulation (EC) No 629/2008 of 2 July 2008 amending Regulation (EC) No 1881/2006.

Eikenberry, B.C.S., Riva-Murray, K., Knightes, C.D., Journey, C.A., Chaser, L.C., Brigham, M.E. and Bradley, P.M. 2015. Optimizing fish sampling for fishMercury bioaccumulation factors. Chemosphere, 135:467-473. http://doi.org/10.1016/j.chemoshere.2 014.12 .068

Espart, A., Artime, S., Tort-Nasarre, G. and Edinson, Y. 2018. Cadmium exposure during pregnancy and lactation, meternofetal and Cd-metallothionen compexes. Metallomics, 10:1359. http://doi.org/10.1039/C8MT00174J.

Ezemonye, L, Tongo, I., Fasipe, P., Ogbeide, O. and Ogbomida E. 2017. Assessment of organochlorine pesticide levels in fruits and vegetables from markets in southern Nigeria. In: Conference proceedings of the $9^{\text {th }}$ International Toxicology Symposium in Africa, $7^{\text {th }} 8^{\text {th }}$ September, 2017, Benin City, Nigeria. pp. 2-3.
Food and Agriculture Organisation. 1983. Compilation of legal limits for hazardous substances in fish and fishery products. FAO Fishery Circular Number 464. 102 pp.

Food Safety Authority of Ireland. 2009. Mercury, Lead, Cadmium, Tin and Arsenic in food. Toxicology fact sheet series, Issue Number 1, May 2009. 13 pp.

Frimpong, E.A., Ansah, Y. B., Amisah, S., Adjei-Boateng, D., Agbo, N.W. and Egna, H. 2014. Effects of two environmental best management practices on pond water and effluent quality and growth of Nile Tilapia, Oreochromis niloticus. Sustainability, 6: 652675. http://doi.org/10.3390/su6020652

Ibrahim, D., Ibrahim, A. S., Paul, E. D., Umar, M. and Zannah, U.A.S. 2018. Determination of some heavy metal content in Tilapia and catfish species from Lake Njuwa, Adamawa state, Nigeria. Journal of Applied Science and Environmental Management, 22(8): 11591165. doi.org/10.4314/jasem.v22i8.3

Igbagara, P.W., Ezekwe, I.C. and Oji, C. $2016 . \quad$ Hydrocarbonoclastic microorganisms and hydrocarbon pollution of groundwater in the Obagi oil fields of Rivers state

Nigeria. TLEP International Journal of Biology and Health Care Practice, 2(1): 19-28

Jang, A., Seo, Y. and Bishop, P.L. 2005. The removal of heavy metals in urban runoff by sorption on mulch. Environmental Pollution, 133(1):117-127. http://doi.org/10.1016/j.envpol.2004.0 5.020

Jayaprabha, N., Balakrishnan, S., Purusothaman, S., Indira, K., Srinivasan, M. and Anantharaman, P. 2014. Bioaccumulation of heavy metals in flying fishes along southeast coast of India. International Food Research Journal, 21(4): 1381-1386.

Johnston, J.E., Lim, E. and Roh, H. 2019. Impact of upstream oil extraction and environmental public health: A review of 
the evidence. Science of the Total Environment, 657: 187-199. doi.org/10.1016/j.scitotenv.2018.11.483 Maurya, P.K. and Malik, D.S. 2018. Bioaccumulation of heavy metals in tissues of selected fish species from Ganga River, India and risk assessment for human health. Human and Ecological Risk. Assessment, http://doi.org/10.1080/10807039.2018. 1456897

Nabizadeh, R., Mahvi, A., Mardani, G. and Yunesian, M. 2005. Study of heavy metals in urban runoff. International Journal of Environmental Science and Technology, 1(4): 325-333. http://doi.org/10.1007/BF03325849

Newstead, J.N., Cousins, I.K. and Giesy, J. 2002. Predicted distribution and ecological risk assessment of a segregated hydrofluoranthene in the Japanese environment. Environmental Science and Technology, 36: 4761- 4769.

Oketola, A.A., Adebisi, A.A. and Morakinyo, O. 2013. Distribution and bioavailability of metals in gasoline contaminated sites in Lagos, Nigeria. The Journal of Solid Waste Technology and Management, 39 (3): 161-220.r

Olaosebikan, B.D. and Raji, A. 2013. Field guide to Nigerian freshwater fishes. Revised Edition. Remi Thomas Press, New Bussa, Nigeria. 144 pp.

Olawuyi, D. S. 2018. Environmental impacts and risks of extractive operations. In: Extraction Industry Law of Africa. Springer, Cham. pp. 269-322. doi.org/10.1007/978-3-319-97664-8_10

Olowu, R.A., Jimoh, A.A., Onwordi, C.T., Ogunnaike, B.A. and Amosu, A.O. 2015. Potential toxic metal concentrations in different aquatic lives harvested from Lagos Island and Epe Lagoons. World Environment, 5(2): 80-89.

Omitoyin, B.O. 2007. Introduction to fish farming in Nigeria. Ibadan University Press, Ibadan, Nigeria. 90 pp.
Ovie, S.O., Ovie, S.O. and Madu, A. 2008. Growth and survival of Heterobranchus longifilis fry in different stocking densities. The Zoologist, 6: 21-26.

Rajeshkumar, S. and Li, X. 2018. Bioaccumulation of heavy metals in fish species from the Meiliang Bay, Taihu Lake, China. Toxicology Reports, 5:288-295. http://doi.org/10.1016/j.toxrep.2018.01 .007

Reddy, K.R. 2014. Removal of heavy metals from urban storm water runoff using different filter materials. Journal of Environmental Chemical Engineering, 2(1): 282-292. http://doi.org/10.1016/j.jece.2013.12.0 20

Reinhold, J. O., Hendriks, A.J., Slager, L.K. and Ohm, M. 1999. Transfer of micro contaminants from sediment to Chironomids and the risk for the pond bat Myotis dasycneme (Chiroptera) preying on them. Aquatic Biology, 33(4): 363-376.

Reuben, R.C., Gyar, S.D. and Aliyu, Y. 2018. Physicochemical and microbiological parameters of water from Rivers in Keffi, Central Nigeria. Microbiology Research Journal International, 24(3): 1-12. http://doi.org/10.9734/MRJI/2018/42 547

Schneider, R.F. 1971. Impact of various heavy metals on the aquatic environment. Technical report Number 2. Environmental Protection Agency Water Quality Office/ Office of Enforcement and Standard Compliance, Denver, Colorado. 22 pp.

United Nations Educational Scientific and Cultural Organization/ World Health Organization/United Nations Environment Programme. 1996. Water Quality Assessments - A Guide to Use of Biota, Sediments and Water in Environmental Monitoring. Second Edition. University Press, Cambridge. 609 pp.

Wangboje, O. M. and Ikhuabe, A. J. (2015). Heavy metals in fish and water from 
River Niger at Agenebode, Edo state, Nigeria. African Journal of Environmental Science and Technology, 9(3): 210-217.

Wangboje, O.M. and Miller, A.M. 2018. Heavy metal profile in a smoked Cynoglossus fish species from selected markets in Owo Town, South Western, Nigeria. International Journal of Fisheries and Aquatic Studies, 6(4): 355-362.

Wangboje, O.M. and Oghenesode, P. A. 2017. Assessment of human health risk in relation to concentrations of some heavy metals in smoke-dried Bonga fish (Ethmalosa fimbriata, Bowdich, 1825) sold in fish markets in Warri, Niger Delta, Nigeria. Federal University Wukari Trends in Science and Technology Journal, 2(1B): 641646. 